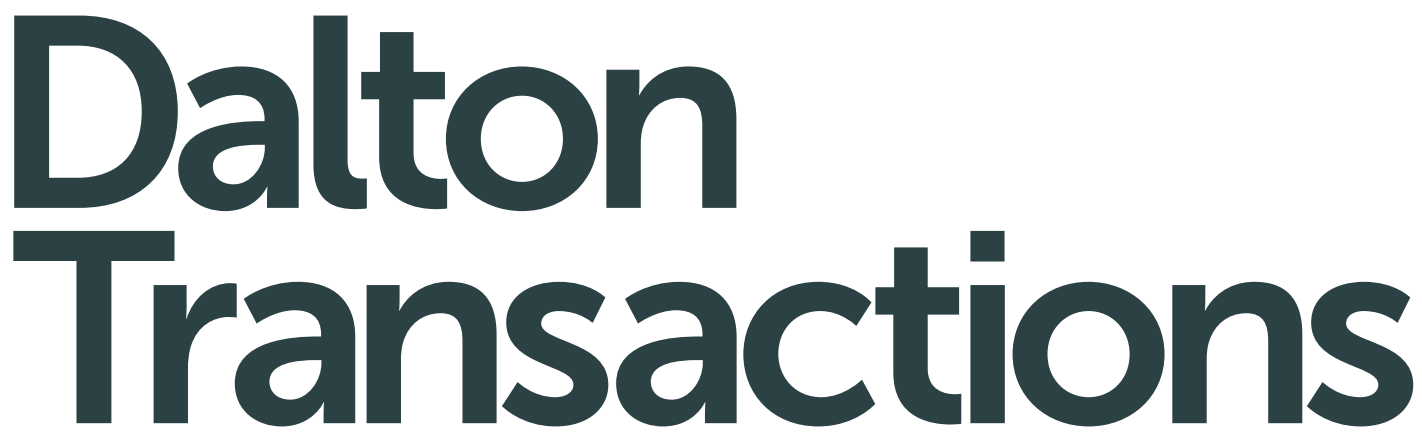

An international journal of inorganic chemistry www.rsc.org/dalton
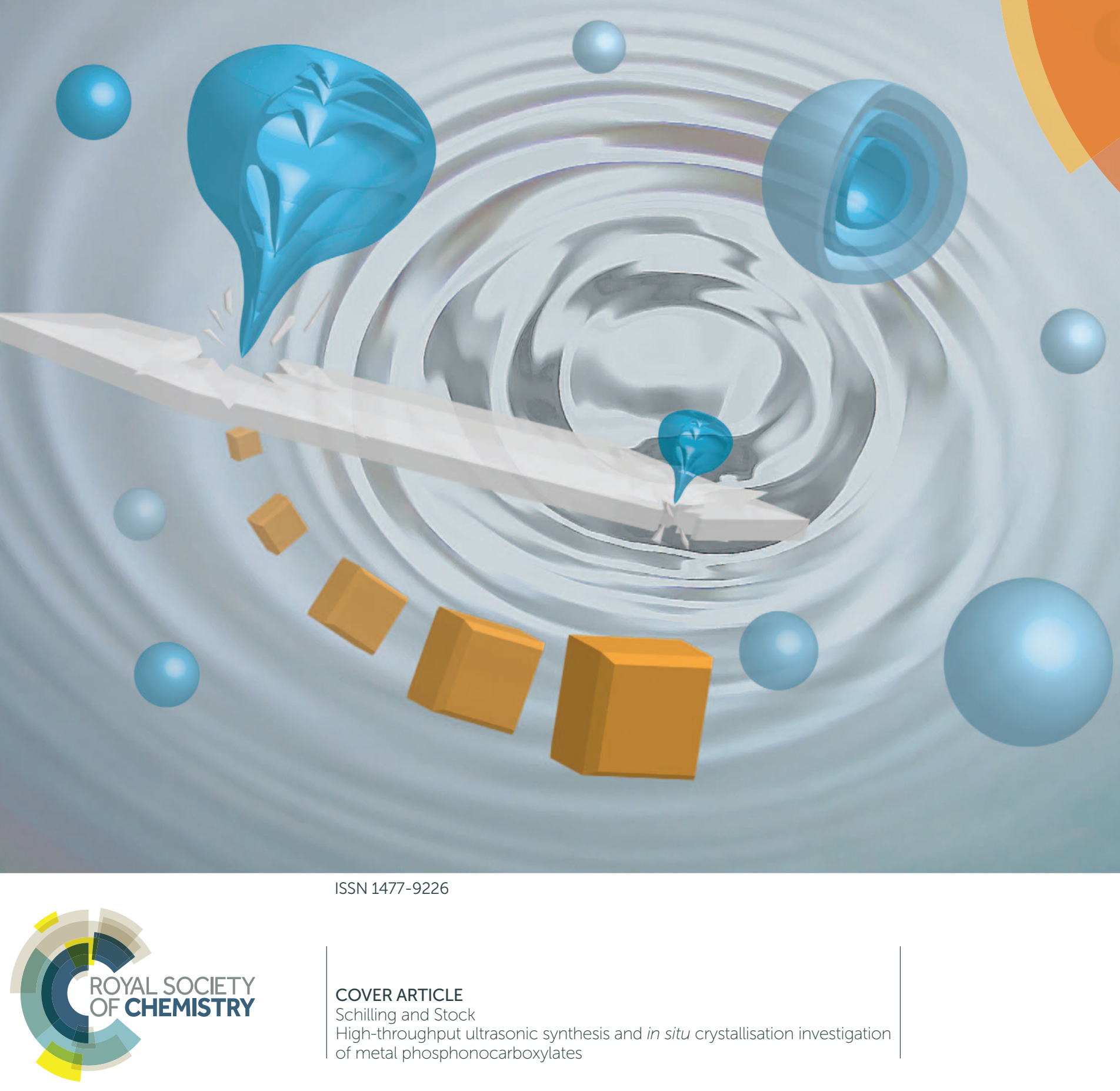
Cite this: Dalton Trans., 2014, 43, 414

Received 18th September 2013, Accepted 27th October 2013

DOI: $10.1039 / \mathrm{c} 3 \mathrm{dt} 52576 \mathrm{~g}$

www.rsc.org/dalton

\section{High-throughput ultrasonic synthesis and in situ crystallisation investigation of metal phosphonocarboxylates $\uparrow$}

\begin{abstract}
Lars-Hendrik Schilling and Norbert Stock*
High-throughput reactions of aqueous solutions of 4-(phosphonomethyl)benzoic acid $\left(\mathrm{H}_{3} \mathrm{PMBC}\right)$ with metal salts were carried out using, for the first time, ultrasonication as well as the previously described conventional heating. On screening the influence of 12 divalent metal ions, two new compounds $\left(\left[\mathrm{Ca}\left(\mathrm{H}_{2} \mathrm{O}\right)_{2}\left(\mathrm{H}_{2} \mathbf{P M B C}\right)_{2}\right]\right.$ and $\left.\left[\mathrm{Ni}\left(\mathrm{H}_{2} \mathrm{O}\right)_{4}\left(\mathrm{H}_{2} \mathbf{P M B C}\right)_{2}\right]\right)$ were discovered. Their formation fields were established by systematically studying the systems $\mathrm{Ni}^{2+}$ or $\mathrm{Ca}^{2+} / \mathrm{H}_{3} \mathrm{PMBC} / \mathrm{KOH}$. Both compounds crystallise in the space group $P \overline{1}\left(\left[\mathrm{Ca}\left(\mathrm{H}_{2} \mathrm{O}\right)_{2}\left(\mathrm{H}_{2} \mathrm{PMBC}\right)_{2}\right]: a=4.6806(9) \AA, b=6.1340(12) \AA, c=17.932(4) \AA, \alpha=\right.$ 83.84(3) $, \beta=89.03(3)^{\circ}, \gamma=85.65(3)^{\circ} ;\left[\mathrm{Ni}_{(}\left(\mathrm{H}_{2} \mathrm{O}\right)_{4}\left(\mathrm{H}_{2} \mathrm{PMBC}\right)_{2}\right]: a=4.7713(10) \AA, b=6.8621(14) \AA, c=$ 16.598(3) $\left.\AA, \alpha=83.42(3)^{\circ}, \beta=89.71(3)^{\circ}, \gamma=83.50(3)^{\circ}\right)$ and contain $\mathrm{MO}_{6}$-octahedra linked to form chains by hydrogen bonded $\left(\mathrm{H}_{2} \mathrm{PMBC}^{-}\right)_{2}$-dimers formed between the carboxylate groups. The formation of $\left[\mathrm{Ni}\left(\mathrm{H}_{2} \mathrm{O}\right)_{4}\left(\mathrm{H}_{2} \mathrm{PMBC}\right)_{2}\right]$ was studied by in situ EDXRD and in situ IR spectroscopy. The increased formation rate of $\left[\mathrm{Ni}\left(\mathrm{H}_{2} \mathrm{O}\right)_{4}\left(\mathrm{H}_{2} \mathbf{P M B C}\right)_{2}\right]$ under ultrasonic irradiation as compared to conventional heating could be unequivocally attributed to the faster dissolution of the ligand $\mathrm{H}_{3} \mathrm{PMBC}$.
\end{abstract}

\section{Introduction}

Ultrasonic synthesis has been mainly applied in the field of organic synthesis, ${ }^{1}$ but it has also been used in the synthesis

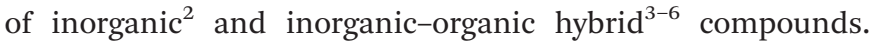
Syntheses under ultrasonic conditions can be generally carried out under relatively mild reaction conditions while locally extreme conditions are present. ${ }^{2,7}$ The main mechanism of ultrasonic energy input is through acoustic cavitation. The ultrasonic vibration causes the formation of bubbles in a liquid. These cavities grow to a critical size until they rapidly collapse. The conditions at the centre of such an implosion are extreme and can reach temperatures of $5000 \mathrm{~K}$ and 1000 atm. ${ }^{8}$ In addition the short time scale results in heating and cooling rates greater than $10^{10} \mathrm{~K} \mathrm{~s}^{-1} \cdot{ }^{9}$ In the vicinity of a solid surface the implosion of cavities can lead to the formation of so-called microjets. These lead to the removal of surface material, thus producing highly reactive surfaces, the dissolution of solid reactants or the decomposition of reaction products. $^{10}$

Institut für Anorganische Chemie, Christian-Albrechts-Universität, Max-Eyth Straße 2, D 24118 Kiel, Germany. E-mail: stock@ac.uni-kiel.de; Fax: +49-431-880-1775; Tel: +49-431-880-1675

$\dagger$ Electronic supplementary information (ESI) available. CCDC 961688 and 961689. For ESI and crystallographic data in CIF or other electronic format see DOI: $10.1039 / \mathrm{c} 3 \mathrm{dt} 52576 \mathrm{~g}$
In the field of inorganic-organic hybrid compounds, the use of ultrasound has been employed mainly to synthesise nano-particular reaction products. ${ }^{7,11}$ Thus metal caboxylates such as $\left[\mathrm{Na}_{16}\left(\mathrm{Ni}_{8} \mathrm{~L}_{12}\right)\left(\mathrm{H}_{2} \mathrm{O}\right)_{20}\left(\mathrm{H}_{3} \mathrm{O}\right)_{4}\right] \cdot \mathrm{CH}_{3} \mathrm{CN} \cdot 18.5 \mathrm{H}_{2} \mathrm{O}\left(\mathrm{H}_{3} \mathrm{~L}=\right.$ 4,5-imidazoledicarboxylic acid), ${ }^{3}\left[\mathrm{Zn}\left(\mathrm{H}_{2} \mathrm{O}\right)(\mathrm{BDC})\right],{ }^{4}$ or MOF-5 $\left(\left[\mathrm{Zn}_{4}\left(\mu_{4}-\mathrm{O}\right)(\mathrm{BDC})_{3}\right]\right)\left(\mathrm{H}_{2} \mathrm{BDC}=\right.$ terephthalic acid $)$ have been described. ${ }^{5}$ A porous zinc imidazolate containing a photoswitchable ligand has also been recently reported. ${ }^{6}$ Though the processing of pre-synthesised phosphonate compounds into nanoscale material has been reported, ${ }^{11}$ to the best of our knowledge no synthesis of metal phosphonates employing ultrasonic synthesis has been reported up to now.

Phosphonate-based inorganic-organic hybrid compounds have been intensively studied due to their immense structural diversity and variability. ${ }^{12,13}$ The introduction of additional functional groups such as amine, ${ }^{14,15}$ sulfonate, $^{12}$ or carboxylate $^{13-16}$ groups allows to further increase the structural complexity. Small changes in the reaction parameters often lead to new phases and therefore high-throughput (HT) methods have been shown to be extremely helpful in the systematic and detailed investigation of phosphonate-based hybrid compounds. ${ }^{13,22}$ However only in situ characterisation techniques allow for the detailed investigation of product formation. ${ }^{17}$ Local structural changes in solid compounds can be monitored by in situ IR-spectroscopy while the crystallisation of compounds can be best investigated using X-ray diffraction experiments. Hence, in situ IR spectroscopy was used, for 


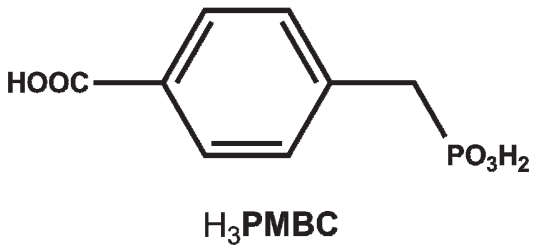

Fig. 1 Structural formula of 4-(phosphonomethyl)benzoic acid $\left(\mathrm{H}_{3} \mathrm{PMBC}\right)$.

example, to study the hydrogenation of carbon monoxide on a CoMo catalyst ${ }^{18}$ or the crystallisation of paracetamol by antisolvent titration. ${ }^{19}$ The formation of crystalline compounds under solvothermal conditions has been investigated employing in situ energy dispersive X-ray diffraction (EDXRD). ${ }^{17}$ Examples are intercalation reactions, ${ }^{20}$ the crystallisation of thiostannates, ${ }^{21}$ thioantimonates, ${ }^{26}$ metal oxides, ${ }^{22}$ coordination compounds, ${ }^{23}$ composites $^{24}$ or metal carboxylates. ${ }^{29}$ We have recently investigated the formation of crystalline metal phosphonates using conventional as well as microwaveassisted heating. ${ }^{14,30}$

Based on our previous work, ${ }^{14,15}$ we have now studied the use of 4-(phosphonomethyl)benzoic acid $\left(\mathrm{H}_{3}\right.$ PMBC, Fig. 1) as a starting material in the synthesis of inorganic-organic hybrid compounds.

Here we report the first application of high-throughput ultrasonic synthesis for the investigation of inorganic-organic hybrid compounds by studying the systems $\mathrm{M}^{2+} / \mathrm{H}_{3} \mathbf{P M B C} /$ $\mathrm{KOH} / \mathrm{H}_{2} \mathrm{O}\left(\mathrm{M}^{2+}=\right.$ various divalent metal ions). In situ EDXRDand IR-spectroscopic crystallisation studies were carried out to establish the influence of ultrasonic cavitation on product formation.

\section{Experimental}

\section{General}

All chemicals are commercially available and were used as received without further purification. Products were characterised by X-ray diffraction using a STOE Stadi P Kombi highthroughput diffractometer, NMR spectroscopy (Bruker Avance 200 spectrometer at $200 \mathrm{MHz}$ ), IR spectroscopy (Bruker ALPHA-FT-IR A220/D-01) and elementary analysis employing a Eurovektor Euro EA Elemental Analyzer. Reactions were observed via in situ EDXRD at HASYLAB F3, DESY Hamburg and in situ IR-spectroscopy using a Mettler Toledo EasyMax ${ }^{\mathrm{TM}}$ automated reactor system.

\section{Synthesis of 4-(phosphonomethyl)benzoic acid ( $\left.\mathrm{H}_{3} \mathrm{PMBC}\right)$}

The ligand $\mathrm{H}_{3}$ PMBC was synthesised according to a literature report ${ }^{16}$ by the reaction of 4 -(bromomethyl)benzoic acid with triethylphosphite and subsequent hydrolysis. In a round bottom flask, a reaction mixture of $1.00 \mathrm{~g}$ (4.65 mmol) 4-(bromomethyl)benzoic acid, $4.00 \mathrm{~mL}(23.3 \mathrm{mmol})$ triethyl phosphite and $20 \mathrm{~mL}$ toluene was heated under reflux for $12 \mathrm{~h}$. Subsequently the solvent and an excess of triethyl phosphite were removed under vacuum and a white solid dispersed in a colourless oil was obtained.

The mixture was treated with $40 \mathrm{~mL}$ toluene and $40 \mathrm{~mL}$ concentrated hydrochloric acid and heated under reflux and fast stirring for $12 \mathrm{~h}$. Solvent and liquid side products were removed under vacuum. The light brown raw product was recrystallised in water thrice to yield $945 \mathrm{mg}(94 \%) \mathrm{H}_{3}$ PMBC.

${ }^{1}$ H NMR (500 MHz, DMSO, Fig. S1 $\dagger$ ): $\delta=7.86\left(2 \mathrm{H}, \mathrm{d},{ }^{3} J_{H, H}\right.$ $\left.=8.08 \mathrm{~Hz}, \mathrm{HOOC}-\mathrm{C}-(\mathbf{C H}-\mathrm{CH})_{2}-\mathrm{C}\right), 7.37\left(2 \mathrm{H}, \mathrm{dd},{ }^{3} J_{H, H}=8.28\right.$ $\left.\mathrm{Hz},{ }^{4} J_{P, H}=2.21 \mathrm{~Hz}, \mathrm{HOOC}-\mathrm{C}-(\mathrm{CH}-\mathrm{CH})_{2}-\mathrm{C}\right), 3.06\left(2 \mathrm{H}, \mathrm{d},{ }^{2} J_{P, H}=\right.$ $\left.21.84 \mathrm{~Hz}, \mathrm{P}-\mathrm{CH}_{2}\right)$ ppm. ${ }^{31} \mathbf{P}$ NMR (200 MHz, DMSO, Fig. S2 $\dagger$ ): $\delta=20.27\left(\mathrm{PO}_{3} \mathrm{H}_{2}\right)$ ppm. Elementary analysis: calcd (\%) for $\mathrm{C}_{8} \mathrm{H}_{9} \mathrm{O}_{5} \mathrm{P}: \mathrm{C} 44.46, \mathrm{H} 4.20$; found: $\mathrm{C} 44.28, \mathrm{H} 4.19$.

\section{High-throughput ultrasonic syntheses}

High-throughput ultrasonic synthesis was carried out in Greiner bio-one Cellstar 24 well cell culture plates which were sealed with viewseal transparent foil and ultrasonicated in the water bath of a Hielscher UIO250MTP high-throughput ultrasound device. The device is specified in more detail in the ESI. $\dagger$

Metal salt screening. First, a metal screening experiment of the system metal salt $/ \mathrm{H}_{3} \mathbf{P M B C} / \mathrm{KOH}$ was carried out in water under ultrasonic irradiation using the molar ratios 1:1:0 and $1: 1: 3$. As metal salts, $\mathrm{MgCl}_{2} \cdot 6 \mathrm{H}_{2} \mathrm{O}, \mathrm{Ca}\left(\mathrm{NO}_{3}\right)_{2} \cdot 4 \mathrm{H}_{2} \mathrm{O}$, $\mathrm{SrCl}_{2} \cdot 6 \mathrm{H}_{2} \mathrm{O}, \quad \mathrm{Ba}\left(\mathrm{NO}_{3}\right)_{2}, \quad \mathrm{Cu}\left(\mathrm{NO}_{3}\right)_{2} \cdot 3 \mathrm{H}_{2} \mathrm{O}, \quad \mathrm{MnCl}_{2} \cdot 2 \mathrm{H}_{2} \mathrm{O}$, $\mathrm{FeCl}_{2} \cdot 4 \mathrm{H}_{2} \mathrm{O}, \mathrm{CoCl}_{2} \cdot 6 \mathrm{H}_{2} \mathrm{O}, \mathrm{NiCl}_{2} \cdot 6 \mathrm{H}_{2} \mathrm{O}, \mathrm{Zn}\left(\mathrm{NO}_{3}\right)_{2} \cdot 6 \mathrm{H}_{2} \mathrm{O}, \mathrm{Pb}-$ $\left(\mathrm{O}_{2} \mathrm{C}_{2} \mathrm{H}_{3}\right)_{2} \cdot 3 \mathrm{H}_{2} \mathrm{O}$ and $\mathrm{SnCl}_{2} \cdot 2 \mathrm{H}_{2} \mathrm{O}$ were used. The reactions were carried out in $1.5 \mathrm{~mL} \mathrm{H}_{2} \mathrm{O}$ and the overall concentration of all reactants was $100 \mathrm{mmol} \mathrm{L}^{-1}$. In sum, 24 reactions were carried out according to the parameters given in Table S2. $\dagger$ For each reaction the ligand and the metal salt were weighed in as a solid, while potassium hydroxide was added as an aqueous solution with a concentration of $2 \mathrm{~mol} \mathrm{~L}^{-1}$. The reaction mixtures were ultrasonicated for $1 \mathrm{~h}$ at a power level of $50 \%$. The products were filtered off and analysed by PXRD.

The systems $\left(\mathrm{Ca}\left(\mathrm{NO}_{3}\right)_{2} \cdot \mathbf{4} \mathrm{H}_{2} \mathrm{O}\right.$ or $\left.\mathrm{NiCl}_{2} \cdot \mathbf{6} \mathrm{H}_{2} \mathrm{O}\right) / \mathbf{H}_{3} \mathrm{PMBC} / \mathrm{KOH}$. Since new phases were discovered during the metal screening experiment using calcium and nickel as the metal ions, the systems $\left(\mathrm{Ca}\left(\mathrm{NO}_{3}\right)_{2} \cdot 4 \mathrm{H}_{2} \mathrm{O}\right.$ or $\left.\mathrm{NiCl}_{2} \cdot 6 \mathrm{H}_{2} \mathrm{O}\right) / \mathrm{H}_{3} \mathrm{PMBC} / \mathrm{KOH}$ were investigated in more detail. All parameters were kept constant and only the molar ratios of the starting materials were varied in smaller steps $(x: y: z=1-2: 1-2: 0-7$, Tables S3 and S5 $\dagger$ ). The products were filtered off and analysed by PXRD.

\section{High-throughput investigations under conventional solvothermal conditions}

Conventional solvothermal synthesis was carried out in a highthroughput autoclave with a capacity of 24 Teflon®-lined reactors with a maximum volume of $2 \mathrm{~mL}$ each. ${ }^{25}$ The ligand was weighed in while the soluble compounds were added as aqueous solvents.

The same parameters as those used in the ultrasonic syntheses were employed for the solvothermal investigation of the system $\mathrm{Ca}\left(\mathrm{NO}_{3}\right)_{2} \cdot 4 \mathrm{H}_{2} \mathrm{O} / \mathrm{H}_{3} \mathbf{P M B C} / \mathrm{KOH}$ (Table $\mathrm{S} 4 \dagger$ ). For the solvothermal HT study of the system $\mathrm{NiCl}_{2} \cdot 6 \mathrm{H}_{2} \mathrm{O} / \mathrm{H}_{3} \mathbf{P M B C} /$ 
$\mathrm{KOH}$ the amount of base was varied in a smaller range $(x: y: z=1-2: 1-2: 0-3.5$, Table $\mathrm{S} 6 \dagger)$. The reactors were heated to $130{ }^{\circ} \mathrm{C}$ within 2 hours (heating rate $=0.88 \mathrm{~K} \mathrm{~min}^{-1}$ ), the temperature was held constant for $52 \mathrm{~h}$ and then slowly lowered to room temperature over a period of $12 \mathrm{~h}$. The products were filtered off and analysed by PXRD.

Highly crystalline, pure phase $\left[\mathrm{Ca}\left(\mathrm{H}_{2} \mathrm{O}\right)_{2}\left(\mathrm{H}_{2} \mathbf{P M B C}\right)_{2}\right]$ and $\left[\mathrm{Ni}\left(\mathrm{H}_{2} \mathrm{O}\right)_{4}\left(\mathrm{H}_{2} \mathbf{P M B C}\right)_{2}\right]$ were obtained using a molar ratio $\left[\mathrm{M}^{2+}\right]$ : $\left[\mathrm{H}_{3} \mathrm{PMBC}\right]:[\mathrm{KOH}]=1: 1: 0$. The compositions were verified by elementary analysis: calcd $(\%)$ for $\mathrm{CaC}_{16} \mathrm{H}_{20} \mathrm{O}_{12} \mathrm{P}_{2}$ : C 37.95, $\mathrm{H}$ 3.98; found: $\mathrm{C} 36.91, \mathrm{H}$ 4.09; calcd (\%) for $\mathrm{NiC}_{16} \mathrm{H}_{20} \mathrm{O}_{12} \mathrm{P}_{2}$ : C 34.26, $\mathrm{H}$ 4.31; found: C 34.91, $\mathrm{H}$ 4.31. Comparison of the measured and simulated PXRD patterns demonstrates also the purity of the reaction products (Fig. S5 and S6†).

\section{In situ EDXRD studies}

The formation of $\left[\mathrm{Ni}\left(\mathrm{H}_{2} \mathrm{O}\right)_{4}\left(\mathrm{H}_{2} \mathbf{P M B C}\right)_{2}\right]$ was studied by in situ EDXRD at HASYLAB, beamline F3 at DESY, Hamburg, Germany. The white beam synchrotron radiation (4 to $55 \mathrm{keV}$ ) was detected by a liquid nitrogen cooled germanium semiconductor detector system. The detector angle was set to approximately $1.9^{\circ}$. The best results were obtained by collimating the beam to $0.2 \times 0.2 \mathrm{~mm}^{2}$. To heat the samples a custommade reactor system heated using an external thermostat (JULABO) was used (the reactor is described in more detail in the ESI $\dagger$ ). The reaction temperature of the reaction mixture is achieved within $3 \mathrm{~min}^{26}$ Ultrasonication was carried out using a Hielscher UP200S ultrasonic processor (diameter of the sonotrode $=7 \mathrm{~mm}$ ) with a power of $200 \mathrm{~W}$ and a frequency of $24 \mathrm{kHz}$.

The linker $\mathrm{H}_{3}$ PMBC (50.4 mg) was dispersed in $2945 \mu \mathrm{L}$ water in a 2-5 $\mathrm{mL}$ glass vial (Biotage $\mathrm{AB}, 351521$ ) and an aqueous solution of $\mathrm{NiCl}_{2} \cdot 6 \mathrm{H}_{2} \mathrm{O}\left(555 \mu \mathrm{L}, 210 \mathrm{mmol} \mathrm{L}{ }^{-1}\right)$ was added. The vial was immediately inserted into the oven at $50{ }^{\circ} \mathrm{C}$ and the ultrasonic probe was lowered into the reaction mixture. The ultrasonication and the EDXRD measurement were started with a time delay of $c a .30 \mathrm{~s}$. In order to investigate the effect of ultrasonication on the product formation the amplitude of the ultrasonic probe was altered in four steps from 20,50 , and 80 to $100 \%$ of the probe's maximal output. The pulse-pulse mode factor was kept constant at $10 \% \mathrm{~s}^{-1}$. The temperature was measured directly after each reaction was stopped (57.6, 58.8, 63.7, and $68.0{ }^{\circ} \mathrm{C}$, respectively). For comparison with conventional heating one reaction was carried out under conventional heating at $60^{\circ} \mathrm{C}$.

\section{In situ IR spectroscopic studies}

The formation of $\left[\mathrm{Ni}\left(\mathrm{H}_{2} \mathrm{O}\right)_{4}\left(\mathrm{H}_{2} \mathbf{P M B C}\right)_{2}\right]$ was also investigated via in situ IR spectroscopy using a Mettler Toledo EasyMax ${ }^{\mathrm{TM}}$ automated reactor system with an integrated heating and cooling control system and equipped with a ReactIR ${ }^{\mathrm{TM}}$ timeresolved ATR-IR spectrometer with an AgX-fiber probe (the reactor system is described in more detail in the ESI $\dagger$ ). The ultrasonic probe (Hielscher UP200S, diameter of the sonotrode $=7 \mathrm{~mm}$ ) was directly immersed in the reaction mixture. The processor was set to $20 \%$ amplitude and the pulse-pulse mode factor was set to $10 \% \mathrm{~s}^{-1}$.

One experiment was carried out at room temperature and two at $50^{\circ} \mathrm{C}$ in water and the molar ratio of $\mathrm{Ni}^{2+}: \mathrm{H}_{3} \mathbf{P M B C}$ was kept constant $(1: 1)$. While one reaction at $50{ }^{\circ} \mathrm{C}$ was carried out starting from a dispersion of $432 \mathrm{mg} \mathrm{H_{3 }} \mathbf{P M B C}$ in $30 \mathrm{~mL}$ of an aqueous solution of $238 \mathrm{mg} \mathrm{NiCl}_{2} \cdot 6 \mathrm{H}_{2} \mathrm{O}$, the other two reactions (at room temperature and $50{ }^{\circ} \mathrm{C}$, respectively) were carried out starting from a clear solution of $432 \mathrm{mg}$ $\mathrm{H}_{3}$ PMBC in $25.2 \mathrm{~mL}$ water, which was obtained in the reactor by ultrasonication. After the ligand was fully dissolved $4754 \mu \mathrm{L}$ of the aqueous solution of $\mathrm{NiCl}_{2} \cdot 6 \mathrm{H}_{2} \mathrm{O}\left(210 \mathrm{mmol} \mathrm{L} \mathrm{L}^{-1}\right)$ were added.

\section{Crystallographic studies}

The compounds $\left[\mathrm{Ca}\left(\mathrm{H}_{2} \mathrm{O}\right)_{2}\left(\mathrm{H}_{2} \mathbf{P M B C}\right)_{2}\right]$ and $\left[\mathrm{Ni}\left(\mathrm{H}_{2} \mathrm{O}\right)_{4}{ }^{-}\right.$ $\left.\left(\mathrm{H}_{2} \mathbf{P M B C}\right)_{2}\right]$ were studied by single-crystal X-ray diffraction. A single crystal of each compound was selected under the polarisation microscope and measured with a IPDS-2 Imaging Plate Diffraction System from STOE \& Cie with graphite-monochromated Mo-K $\mathrm{K}_{\alpha}$ radiation $(\lambda=0.71073 \AA)$ at $293 \mathrm{~K}$. The data were corrected for Lorentz polarisation and absorption effects. The crystal structures were solved by direct methods using SHELXS- $97^{27}$ and the refinement was performed against $F^{2}$ using SHELXL-97. ${ }^{27}$ All $\mathrm{H}$ atoms connected to carbon atoms were located using a riding model with $\mathrm{C}-\mathrm{H}=0.97 \AA$ for aliphatic $\mathrm{H}$ atoms and $\mathrm{C}-\mathrm{H}=0.93 \AA$ for aromatic $\mathrm{H}$ atoms and were refined isotropically with $U_{\text {iso }}(\mathrm{H})=1.2 U_{\text {eq }}(\mathrm{C})$. The $\mathrm{H}$ atoms connected to oxygen atoms were located in the difference map, their bond lengths were set to ideal values of $0.82 \AA$ and finally they were refined using a riding model with $U_{\text {iso }}(\mathrm{H})=1.5 U_{\text {eq }}(\mathrm{O})$.

\section{Results and discussion}

\section{High throughput investigations}

High-throughput ultrasonic synthesis was implemented for the metal screening and focused investigation of aqueous reactions of 4 -(phosphonomethyl)benzoic acid $\left(\mathrm{H}_{3} \mathbf{P M B C}\right)$ with salts of different divalent metal ions $(\mathrm{M}=\mathrm{Mg}, \mathrm{Ca}, \mathrm{Sr}, \mathrm{Ba}, \mathrm{Mn}$, Fe, Co, Ni, Cu, Zn, Pb, Sn). Two metal salt: $\mathrm{H}_{3} \mathbf{P M B C}: \mathrm{KOH}$ molar ratios (1:1:0 and $1: 1: 3)$ were studied. Addition of a base into the starting mixture mainly leads to clear solutions or the formation of products of low crystallinity at the end of the reaction. In the absence of a base four highly crystalline products are observed while the others are either X-ray amorphous or of low crystallinity (Fig. S3†). Two of the crystalline compounds are known $\left(\left[\mathrm{Mn}\left(\mathrm{H}_{2} \mathrm{O}\right)_{2}\left(\mathrm{H}_{2} \mathbf{P M B C}\right)_{2}\right]^{15}\right.$ and $\left.\left[\mathrm{Zn}\left(\mathrm{H}_{2} \mathrm{O}\right)_{4}\left(\mathrm{H}_{2} \mathbf{P M B C}\right)_{2}\right]^{14}\right)$ and two new hybrid compounds $\left(\left[\mathrm{Ca}\left(\mathrm{H}_{2} \mathrm{O}\right)_{2}\left(\mathrm{H}_{2} \mathbf{P M B C}\right)_{2}\right]\right.$ and $\left.\left[\mathrm{Ni}\left(\mathrm{H}_{2} \mathrm{O}\right)_{4}\left(\mathrm{H}_{2} \mathbf{P M B C}\right)_{2}\right]\right)$ were discovered in this experiment (Fig. 2).

A more detailed investigation using the $\mathrm{Ca}^{2+}$ and $\mathrm{Ni}^{2+}$ salts was subsequently carried out using the HT ultrasonic reactor as well as HT conventional solvothermal conditions. The results of the investigation of the system $\mathrm{Ca}\left(\mathrm{NO}_{3}\right)_{2} \cdot 4 \mathrm{H}_{2} \mathrm{O}$ / 

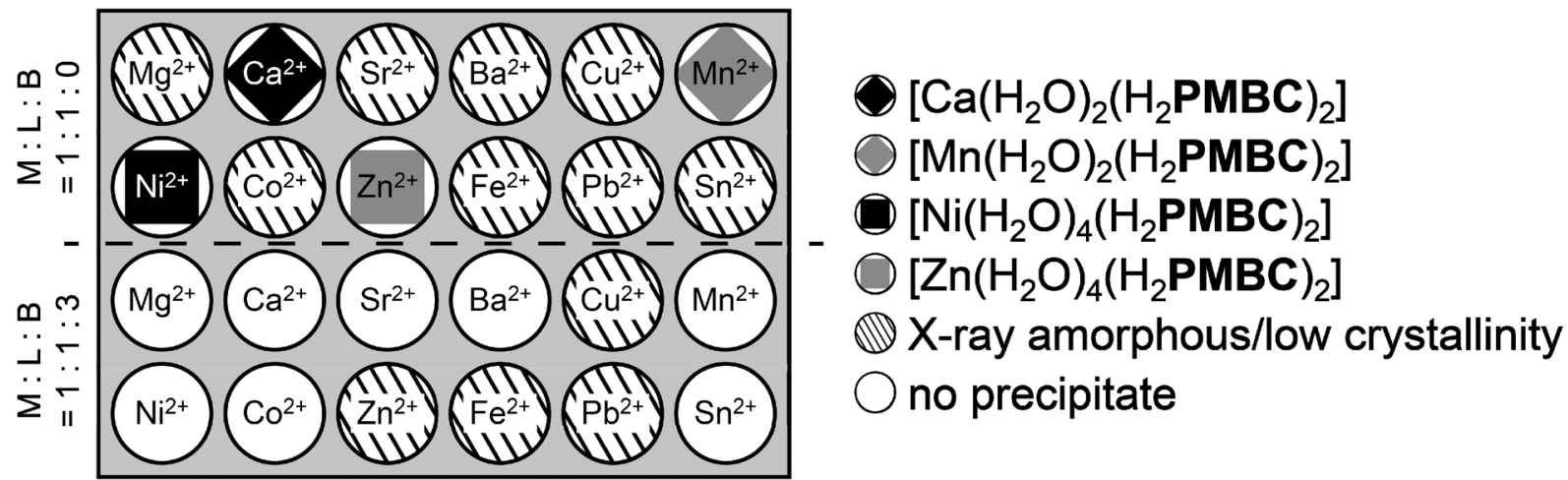

Fig. 2 Outline and results of the metal screening investigation using high-throughput ultrasonic synthesis. Molar ratios of metal salt : $\mathrm{H}_{3} \mathrm{PMBC}: \mathrm{KOH}$ in the reaction mixture are depicted. The reaction products are symbolised by different backgrounds.
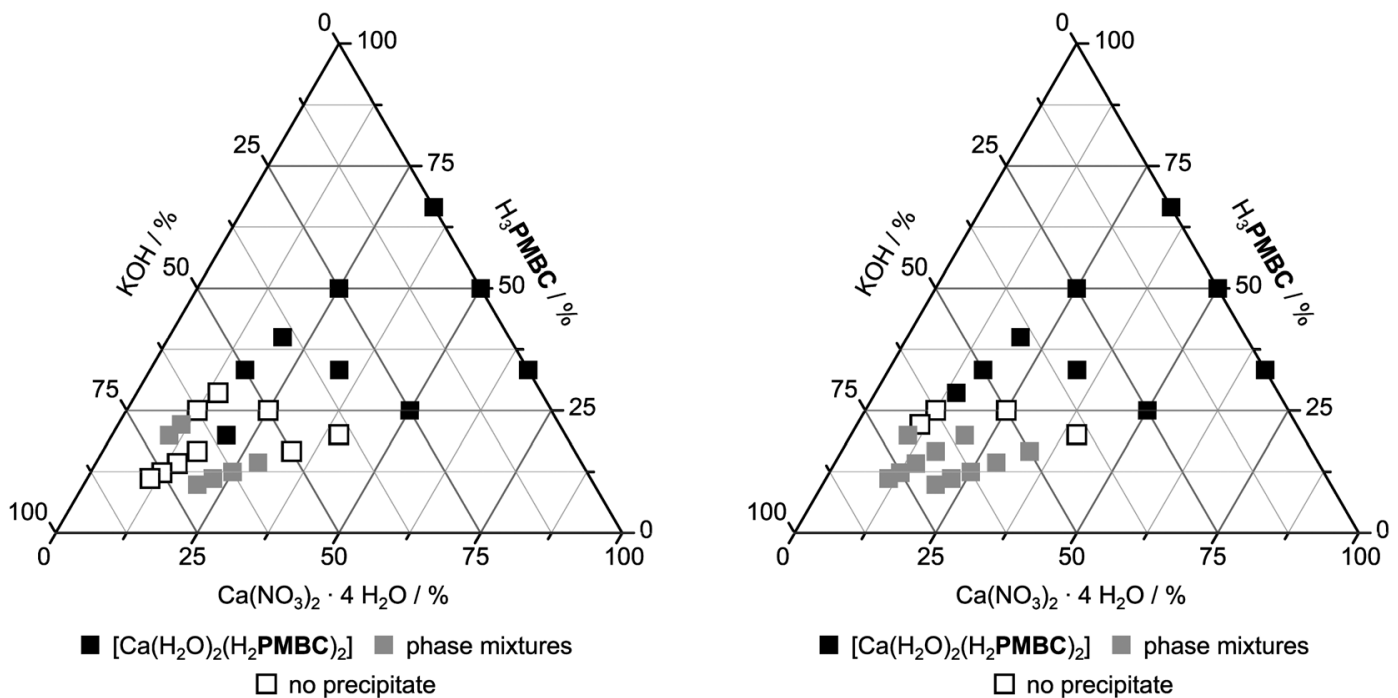

Fig. 3 Results of the investigation of the system $\mathrm{Ca}\left(\mathrm{NO}_{3}\right)_{2} \cdot 4 \mathrm{H}_{2} \mathrm{O} / \mathrm{H}_{3} \mathrm{PMBC} / \mathrm{KOH}$ studied by $\mathrm{HT}$ ultrasonic (left, $50 \%$ power, $1 \mathrm{~h}\left(T_{\max }=70{ }^{\circ} \mathrm{C}\right)$ ) and $\mathrm{HT}$ conventional synthesis (right, $130^{\circ} \mathrm{C}, 52 \mathrm{~h}$ ). The products were analysed by PXRD.

$\mathrm{H}_{3} \mathbf{P M B C} / \mathrm{KOH}$ are depicted in Fig. 3. At low concentrations of potassium hydroxide the crystalline phase $\left[\mathrm{Ca}\left(\mathrm{H}_{2} \mathrm{O}\right)_{2}{ }^{-}\right.$ $\left.\left(\mathrm{H}_{2} \mathbf{P M B C}\right)_{2}\right]$ is formed. At higher base concentrations either no precipitate or products of low crystallinity were observed. At the molar ratio 1:1:1 single-crystalline colourless needles were obtained and subsequently analysed by single-crystal X-ray diffraction.

The results of the system $\mathrm{NiCl}_{2} \cdot 6 \mathrm{H}_{2} \mathrm{O} / \mathrm{H}_{3} \mathrm{PMBC} / \mathrm{KOH}$ are depicted in Fig. 4. At low amounts of potassium hydroxide the compound $\left[\mathrm{Ni}\left(\mathrm{H}_{2} \mathrm{O}\right)_{4}\left(\mathrm{H}_{2} \mathbf{P M B C}\right)_{2}\right]$ is found independently of the synthesis method employed. At higher base concentrations either X-ray amorphous reaction products or no precipitates were formed under ultrasonic reaction conditions $(t=1 \mathrm{~h}$, $\left.50{ }^{\circ} \mathrm{C}\right)$. In contrast, the solvothermal route $\left(t=130{ }^{\circ} \mathrm{C}, 24 \mathrm{~h}\right)$ leads at higher concentrations to clear solutions and further increase of the amount of base results in the formation of a crystalline product (Fig. S4†), which could not be further characterised due to variations in the composition. At the molar ratios 1:1:0 single-crystalline light green needles were obtained and subsequently analysed by single-crystal X-ray diffraction.

The crystal structures of $\left[\mathrm{Ca}\left(\mathrm{H}_{2} \mathrm{O}\right)_{2}\left(\mathrm{H}_{2} \mathbf{P M B C}\right)_{2}\right]$ and $\left[\mathrm{Ni}\left(\mathrm{H}_{2} \mathrm{O}\right)_{4}\left(\mathrm{H}_{2} \text { PMBC }\right)_{2}\right]$ were determined from single-crystal $\mathrm{X}$-ray diffraction measurements. Detailed information about the crystal data and structure determinations is summarised in Table 1. Selected interatomic distances and bond angles are given in Tables S7 and S8, $\uparrow$ respectively. The hydrogen bonds in the structure are detailed in Table 2. The measured PXRD patterns of $\left[\mathrm{Ca}\left(\mathrm{H}_{2} \mathrm{O}\right)_{2}\left(\mathrm{H}_{2} \text { PMBC }\right)_{2}\right]$ and $\left[\mathrm{Ni}\left(\mathrm{H}_{2} \mathrm{O}\right)_{4}\left(\mathrm{H}_{2} \text { PMBC }\right)_{2}\right]$ obtained by conventional as well as ultrasonic synthesis and the comparison with the calculated PXRD patterns are shown in Fig. S5 and S6, $\uparrow$ respectively.

The asymmetric unit of the calcium phosphonocarboxylate is shown in Fig. 5 and it contains one $\mathrm{Ca}^{2+}$ and $\mathrm{H}_{2} \mathbf{P M D C}{ }^{-}$ion each and one water molecule. The $\mathrm{Ca}^{2+}$-ions are located at an inversion centre and are octahedrally surrounded by the 

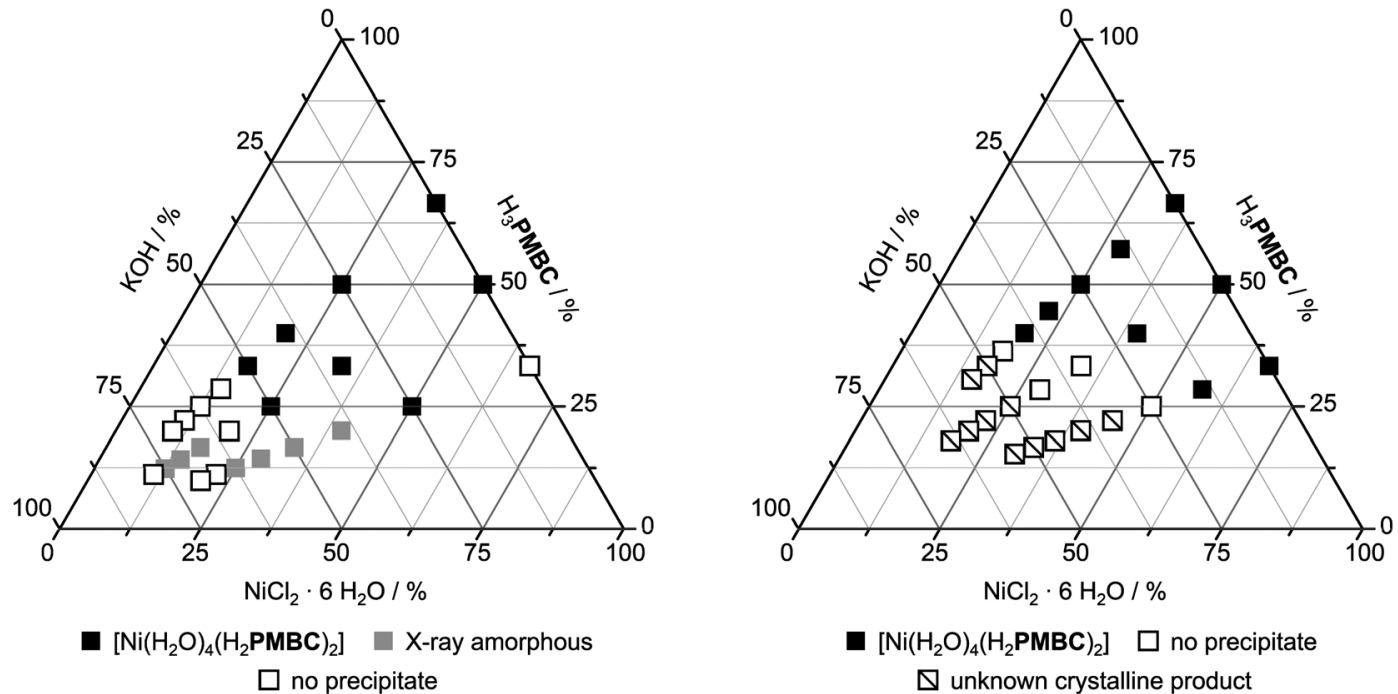

Fig. 4 Ternary diagram of the results of the system $\mathrm{NiCl}_{2} \cdot 6 \mathrm{H}_{2} \mathrm{O} / \mathrm{H}_{3} \mathrm{PMBC} / \mathrm{KOH}$ studied by $\mathrm{HT}$ ultrasonic (left, $50 \%$ power, $1 \mathrm{~h}\left(T_{\max }=70{ }^{\circ} \mathrm{C}\right)$ ) and $\mathrm{HT}$ conventional synthesis (right, $130{ }^{\circ} \mathrm{C}, 52 \mathrm{~h}$ ). The products were analysed by PXRD.

Table 1 Crystal data and structural refinement for $\left[\mathrm{Ca}\left(\mathrm{H}_{2} \mathrm{O}\right)_{2}\left(\mathrm{H}_{2} \mathrm{PMBC}\right)_{2}\right]$ and $\left[\mathrm{Ni}\left(\mathrm{H}_{2} \mathrm{O}\right)_{4}\left(\mathrm{H}_{2} \mathrm{PMBC}\right)_{2}\right]$

\begin{tabular}{|c|c|c|}
\hline $\begin{array}{l}\text { Empirical formula } \\
T / \mathrm{K}\end{array}$ & $\begin{array}{l}\mathrm{CaC}_{16} \mathrm{H}_{20} \mathrm{O}_{12} \mathrm{P}_{2} \\
293\end{array}$ & $\begin{array}{l}\mathrm{NiC}_{16} \mathrm{H}_{24} \mathrm{O}_{14} \mathrm{P}_{2} \\
293\end{array}$ \\
\hline Wavelength/Å & 0.71073 & 0.71073 \\
\hline Crystal system & Triclinic & Triclinic \\
\hline Space group & $P \overline{1}$ & $P \overline{1}$ \\
\hline a/Å & $4.6806(9)$ & $4.7713(10)$ \\
\hline$b / \AA$ & $6.1340(12)$ & $6.8621(14)$ \\
\hline$c / \AA ̊ \AA$ & $17.932(4)$ & $16.598(3)$ \\
\hline$\alpha /{ }^{\circ}$ & $83.84(3)$ & $83.42(3)$ \\
\hline$\beta /{ }^{\circ}$ & $89.03(3)$ & $89.71(3)$ \\
\hline$\gamma /{ }^{\circ}$ & $85.65(3)$ & $83.50(3)$ \\
\hline$V / \AA^{3}$ & $510.38(17)$ & $536.36(19)$ \\
\hline$Z$ & 1 & 1 \\
\hline$D_{\text {calc. }} / \mathrm{g} \mathrm{cm}^{-3}$ & 1.647 & 1.737 \\
\hline$\mu / \mathrm{mm}^{-1}$ & 0.528 & 1.127 \\
\hline$F(000)$ & 262 & 290 \\
\hline GoF on $F^{2}$ & 0.885 & 1.119 \\
\hline$R_{1}[I>2 \sigma(I)]^{a}$ & 0.0660 & 0.0372 \\
\hline $\mathrm{w} R_{2}[I>2 \sigma(I)]^{b}$ & 0.0637 & 0.0812 \\
\hline Data/restraints/parameters & $2768 / 0 / 143$ & $2458 / 0 / 152$ \\
\hline Largest diff. peak and hole $/ \mathrm{e} \AA^{-3}$ & $0.273 /-0.263$ & $0.282 /-0.433$ \\
\hline
\end{tabular}

oxygen atoms of the water molecules (O4) and the phosphonate groups $(\mathrm{O} 1, \mathrm{O} 2)$.

The $\mathrm{CaO}_{6}$ polyhedra are bridged by $\mathrm{HO}_{3} \mathrm{P}$-groups to form one-dimensional chains along [100] which are further stabilised by $\mathrm{O} 3-\mathrm{H} 11 \cdots \mathrm{O} 2$ hydrogen bonds (Fig. 6, left). These chains are connected into layers along [211] by hydrogen bonds between the carboxylic acid groups of two ligand mole-

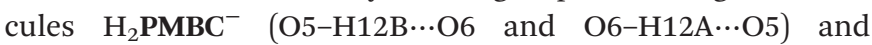
further by $\mathrm{O} 4-\mathrm{H} 9 \cdots \mathrm{O} 2$ hydrogen bonds into a three-dimensional structure (Fig. 6, right).

The crystal structures of $\left[\mathrm{Ni}\left(\mathrm{H}_{2} \mathrm{O}\right)_{4}\left(\mathrm{H}_{2} \mathbf{P M B C}\right)_{2}\right]$ and previously reported $\left[\mathrm{Zn}\left(\mathrm{H}_{2} \mathrm{O}\right)_{4}\left(\mathrm{H}_{2} \mathbf{P M B C}\right)_{2}\right]$ are isomorphous. ${ }^{14}$ The asymmetric unit of $\left[\mathrm{Ni}\left(\mathrm{H}_{2} \mathrm{O}\right)_{4}\left(\mathrm{H}_{2} \text { PMBC }\right)_{2}\right]$ is shown in Fig. 7
Table 2 Hydrogen bonds in the structure of $\left[\mathrm{Ca}\left(\mathrm{H}_{2} \mathrm{O}\right)_{2}\left(\mathrm{H}_{2} \mathrm{PMBC}\right)_{2}\right]$ and $\left[\mathrm{Ni}\left(\mathrm{H}_{2} \mathrm{O}\right)_{4}\left(\mathrm{H}_{2} \mathrm{PMBC}\right)_{2}\right]$

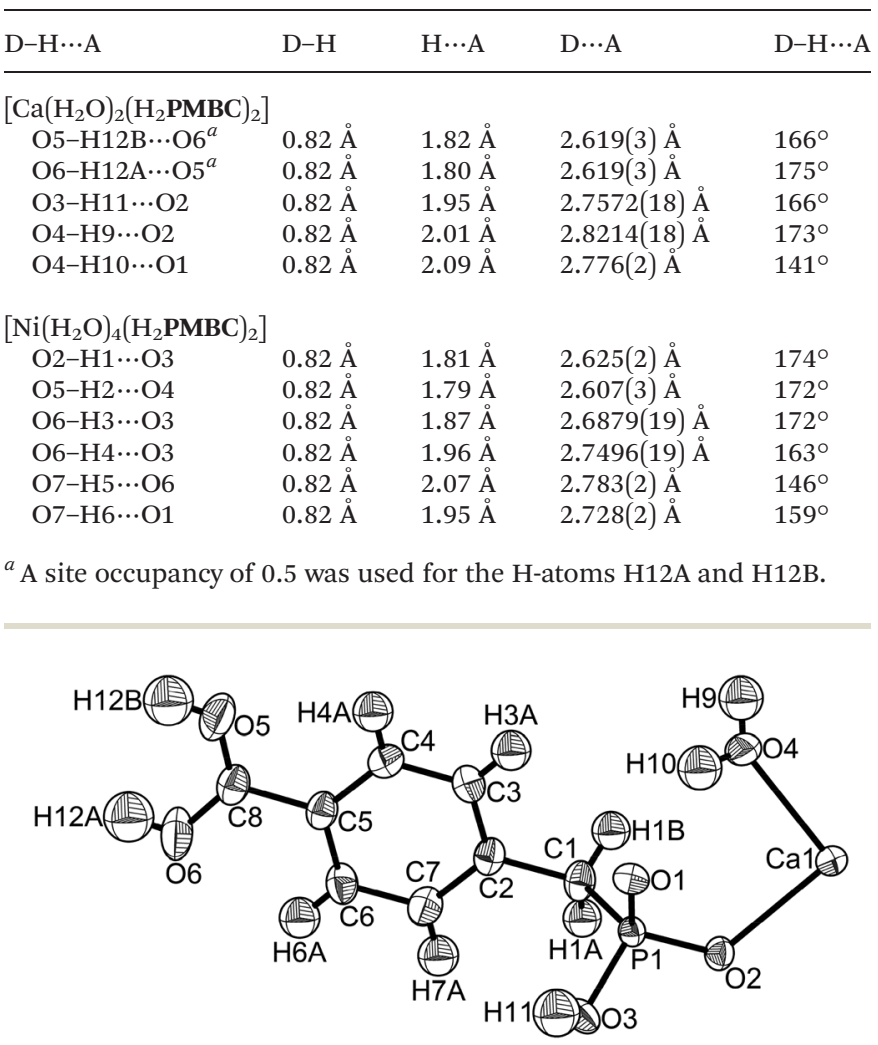

Fig. 5 Asymmetric unit of $\left[\mathrm{Ca}\left(\mathrm{H}_{2} \mathrm{O}\right)_{2}\left(\mathrm{H}_{2} \mathrm{PMBC}\right)_{2}\right]$. A site occupancy of 0.5 was used for the $\mathrm{H}$-atoms $\mathrm{H} 12 \mathrm{~A}$ and $\mathrm{H} 12 \mathrm{~B}$.

and it contains one $\mathrm{Ni}^{2+}$ and $\mathrm{H}_{2}$ PMDC ${ }^{-}$each and two water molecules. The $\mathrm{Ni}^{2+}$-ions are located at an inversion centre and are octahedrally surrounded by oxygen atoms of the two water molecules (O6 and O7) and one phosphonate group (O1). 

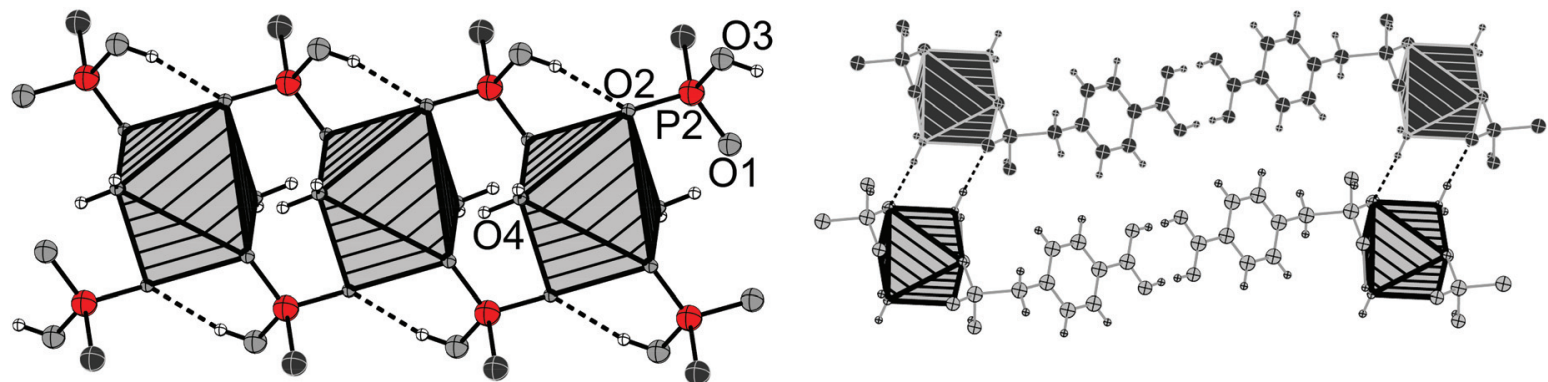

Fig. 6 Crystal structure of $\left[\mathrm{Ca}\left(\mathrm{H}_{2} \mathrm{O}\right)_{2}\left(\mathrm{H}_{2} \mathrm{PMBC}\right)_{2}\right]$. $\mathrm{CaO}_{6}$-polyhedra bridged by phosphonate groups (left) are connected by hydrogen bonds between the carboxylic acid groups of adjacent $\mathrm{H}_{2} \mathrm{PMBC}^{-}$ions. The formation of $\mathrm{O}-\mathrm{H} \cdots \mathrm{OP}$ bonds leads to the connection of adjacent layers (right) - two layers are distinguished by different shades.

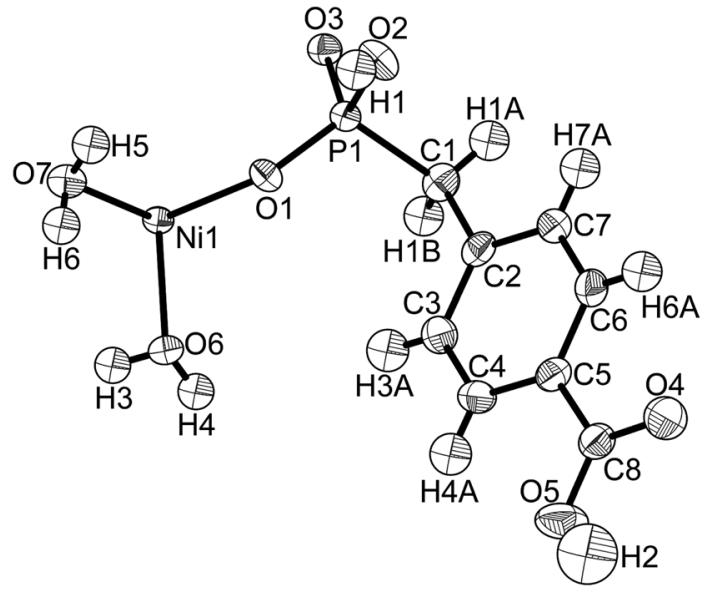

Fig. 7 Asymmetric unit of $\left[\mathrm{Ni}\left(\mathrm{H}_{2} \mathrm{O}\right)_{4}\left(\mathrm{H}_{2} \mathrm{PMBC}\right)_{2}\right]$.

$\mathrm{NiO}_{6}$-polyhedra are connected in the [100]-direction by

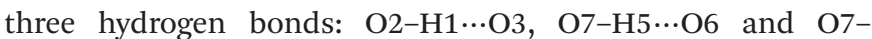
H6 ...O1 (Fig. 8, left) to form chains. Two ligand molecules $\mathrm{H}_{2} \mathbf{P M B C}^{-}$form a dimer by $\mathrm{O} 5-\mathrm{H} 2 \cdots \mathrm{O} 4$ hydrogen bonds between the carboxylic acid groups and connect the $\mathrm{NiO}_{6}$-polyhedra to form one-dimensional chains along [211]; thus layers are obtained (Fig. 8, right). These layers are connected in the [010]-direction by $\mathrm{O} 6-\mathrm{H} 4 \cdots \mathrm{O} 3$ bonds to form the three-dimensional network (Fig. 8, right).
In addition to these hydrogen bonds the structure contains another hydrogen bond (O6-H3 ‥O3) from one of the coordinating water molecules to a neighbouring phosphonate group of the same chain.

Both compounds $\left[\mathrm{Ca}\left(\mathrm{H}_{2} \mathrm{O}\right)_{2}\left(\mathrm{H}_{2} \mathbf{P M B C}\right)_{2}\right]$ and $\left[\mathrm{Ni}\left(\mathrm{H}_{2} \mathrm{O}\right)_{4}{ }^{-}\right.$ $\left.\left(\mathrm{H}_{2} \mathbf{P M B C}\right)_{2}\right]$ crystallise in the space group $P \overline{1}$. Compared to the compounds based on $\mathrm{H}_{3} \mathbf{P M B C}$ reported in the literature ${ }^{18-20}$ they show several similarities. The reported compounds (Table $\mathrm{S} 1 \dagger$ ) were all obtained in solvothermal syntheses and predominantly crystallise in the space group $P \overline{1}$. Common structural motifs in these structures are isolated metal-oxygenpolyhedra and hydrogen bonds between carboxylic acid groups - both motifs are also observed in $\left[\mathrm{Ca}\left(\mathrm{H}_{2} \mathrm{O}\right)_{2}\left(\mathrm{H}_{2} \mathbf{P M B C}\right)_{2}\right]$ and $\left[\mathrm{Ni}\left(\mathrm{H}_{2} \mathrm{O}\right)_{4}\left(\mathrm{H}_{2} \mathbf{P M B C}\right)_{2}\right]$.

\section{In situ EDXRD crystallisation measurements}

The formation of $\left[\mathrm{Ni}\left(\mathrm{H}_{2} \mathrm{O}\right)_{4}\left(\mathrm{H}_{2} \mathbf{P M B C}\right)_{2}\right]$ was investigated using ultrasonic reaction conditions as well as conventional heating at HASYLAB, beamline F3 at DESY, Hamburg, Germany. While the conventional synthesis was carried out under stirring at $60{ }^{\circ} \mathrm{C}$, the amplitude of the ultrasonic horn was varied between 20 and $100 \%$. The spectra were recorded in time intervals of $1 \mathrm{~min}$ each (Fig. 9). The intensity of the 001 peak was determined by integration and used for the evaluation. The reaction progress $\alpha$ was calculated by normalising the
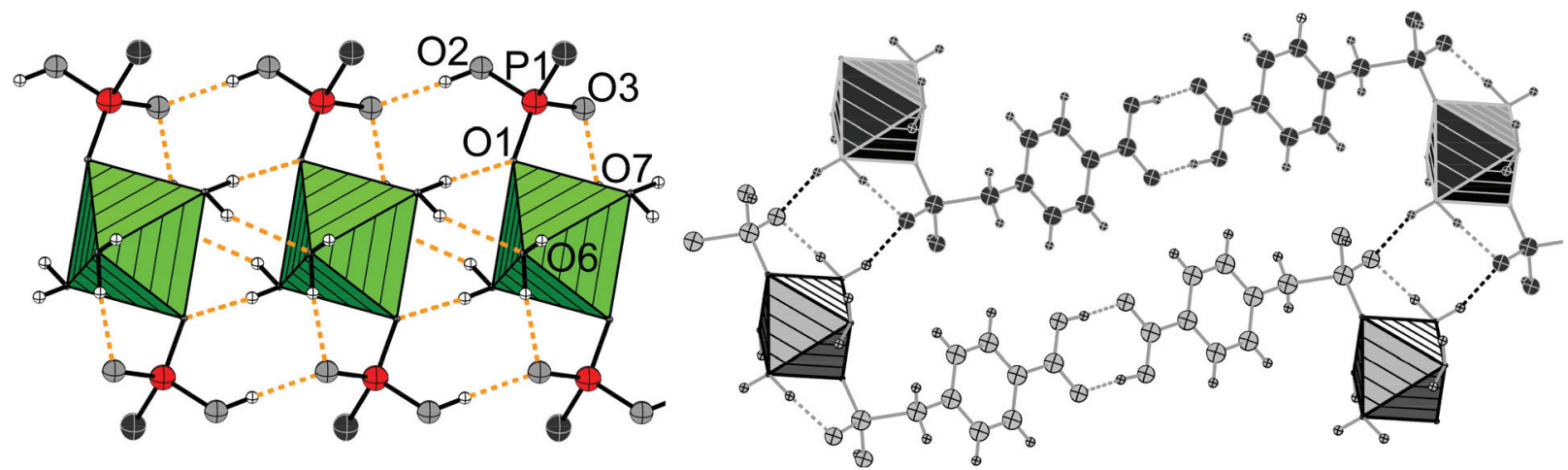

Fig. $8 \mathrm{NiO}_{6}$-polyhedra connected into chains via hydrogen bonds along [100] (left). Two chains (coloured light grey and dark grey) formed by $\left(\mathrm{H}_{2} \mathrm{PMBC}^{-}\right)_{2}$-dimers and connected by hydrogen bonds into a 3D structure viewed along the a-axis (right). 


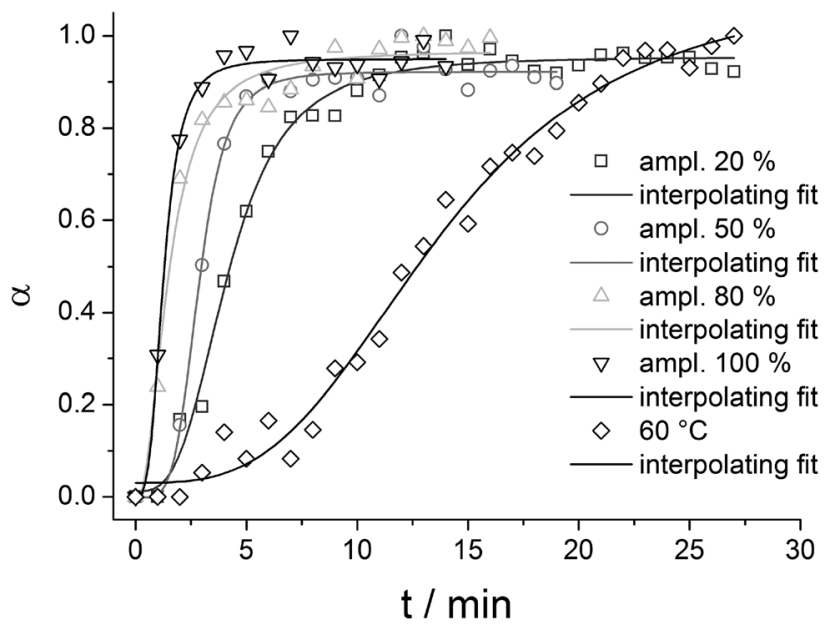

Fig. 9 Reaction progress of the formation of $\left[\mathrm{Ni}\left(\mathrm{H}_{2} \mathrm{O}\right)_{4}\left(\mathrm{H}_{2} \mathrm{PMBC}\right)_{2}\right]$ as observed from the intensity of the 001 peak. The first four reactions were carried out under ultrasonication, while the last one was carried out at $60^{\circ} \mathrm{C}$ under stirring and conventional heating.

intensities to 1 and the results of these measurements are shown in Fig. 9.

Though the quality of the data is insufficient to allow for quantitative analysis of the measurements, qualitative comparisons can be made. The induction times as well as the time periods before full crystallisation depend on the synthesis method as well as the amplitude of the ultrasonic horn. The reaction rates of ultrasonic reactions are clearly significantly higher than the one of the reaction carried out under conventional heating. Higher amplitudes result in a noticeable increase in the reaction rate. We attribute this to higher rates of cavitation caused by the higher energy input of the more intense waves (the intensity of a mechanical wave scales with the square of its amplitude). The observed effect cannot be attributed merely to the reaction temperature since the temperature of the reaction mixtures after ultrasonication at $20 \%$ amplitude is $57.6^{\circ} \mathrm{C}$.

\section{In situ IR spectroscopic studies}

The acceleration of the formation of $\left[\mathrm{Ni}\left(\mathrm{H}_{2} \mathrm{O}\right)_{4}\left(\mathrm{H}_{2} \mathbf{P M B C}\right)_{2}\right]$ due to ultrasonication must be due to the implosive collapse of cavitations, which occurs in the pure solution or in the vicinity of particles of the starting materials. Since $\mathrm{H}_{3} \mathbf{P M B C}$ only slowly dissolves in water, the rate determining step in the formation of $\left[\mathrm{Ni}\left(\mathrm{H}_{2} \mathrm{O}\right)_{4}\left(\mathrm{H}_{2} \mathbf{P M B C}\right)_{2}\right]$ could be the dissolution of the ligand, a process which would be assisted by the formation of microjets.

In order to prove this hypothesis the reaction progress was investigated by in situ IR spectroscopy, which permits the timedependent, semiquantitative determination of the concentration of linker molecules in solution and the solid reaction product. Hence three reactions were carried out, one starting (at $50^{\circ} \mathrm{C}$ ) from a reaction mixture in which the ligand is only dispersed in water and two (at room temperature and $50{ }^{\circ} \mathrm{C}$ ) where a clear solution of the linker, obtained by ultrasonication in the reactor, was combined with the solution of the metal salt. The time-dependent IR spectra of two of these reactions are depicted in Fig. 10.

Upon addition of the Ni-salt solution the background intensity of the spectra changes abruptly. Subsequently new
A)

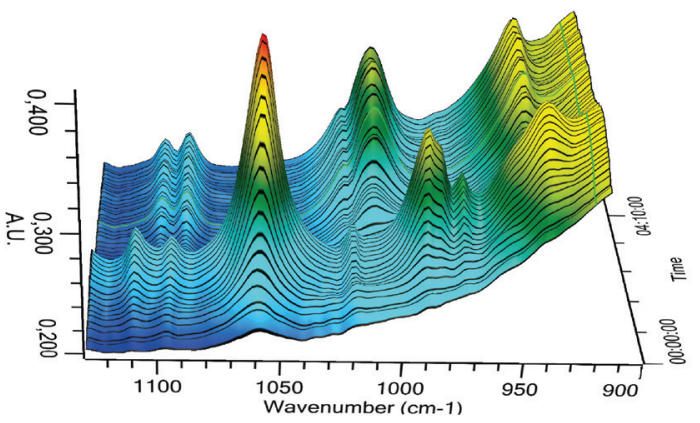

C)

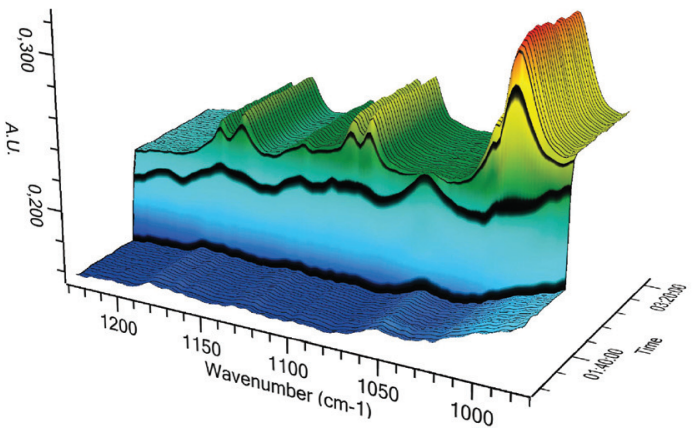

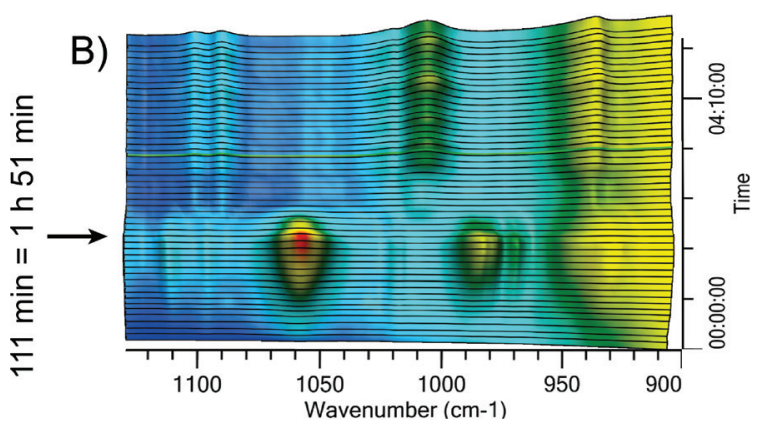

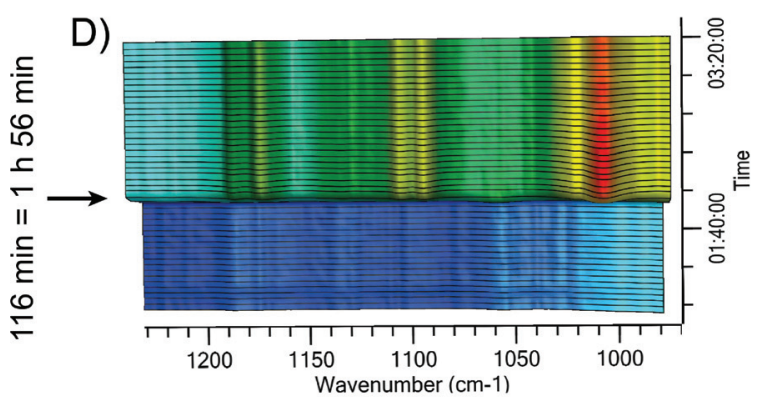

Fig. 10 Typical sets of time-dependent IR spectra. Experiments were carried out at room temperature (A and $B)$ and at $50{ }^{\circ} \mathrm{C}(\mathrm{C}$ and $\mathrm{D})$ starting from clear solutions. 


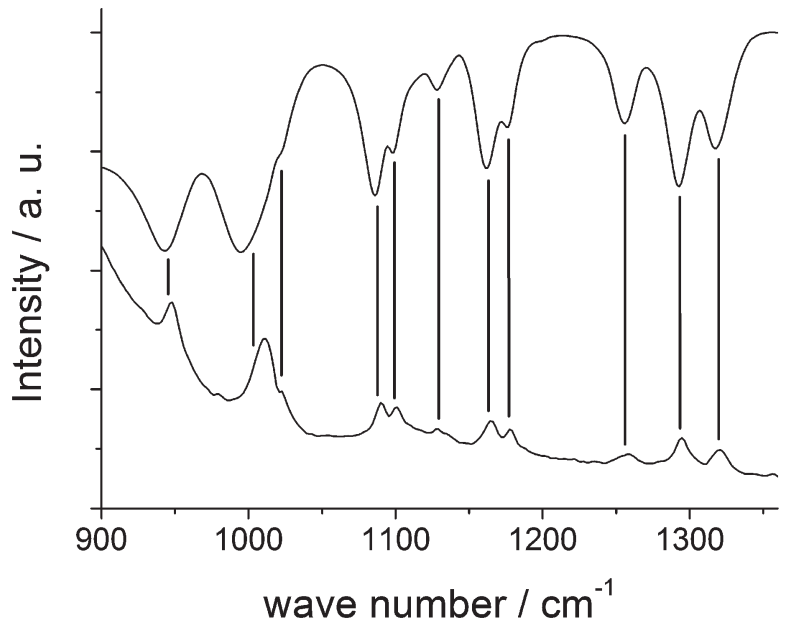

Fig. 11 Comparison of the IR spectra of the reaction mixture after full crystallisation (bottom) with the microcrystalline product obtained in autoclaves (top).

bands that are due to the formation of the final product are observed.

The comparison of the IR spectra of the final product in the in situ experiment and the final product obtained by solvothermal synthesis is depicted in Fig. 11. The IR bands at 944 and $995(\mathrm{P}=\mathrm{O}), 1021,1086(\mathrm{C}-\mathrm{O}-\mathrm{H}), 1099(\mathrm{P}=\mathrm{O})-\mathrm{O}-\mathrm{H})$, $1128,1162,1177,1256(\mathrm{P}=\mathrm{O}), 1293(\mathrm{P}=\mathrm{O})$ and 1318 (carboxylate group) $\mathrm{cm}^{-1}$ as measured by the conventional IR spectrometer are characteristic of $\left[\mathrm{Ni}\left(\mathrm{H}_{2} \mathrm{O}\right)_{4}\left(\mathrm{H}_{2} \mathbf{P M B C}\right)_{2}\right]$ and correspond to the bands at $948,1011,1022,1090,1101,1128$, $1164,1177,1258,1295$ and $1321 \mathrm{~cm}^{-1}$ as measured by the in situ IR spectrometer. These assignments are based on literature data. ${ }^{28}$

The in situ measurement (Fig. 10A and B) at room temperature and starting from clear solutions can be correlated to the processes occurring in the reaction. During the first $111 \mathrm{~min}$ the dissolution of the linker molecules can be followed by the characteristic $\mathrm{P}=\mathrm{O}$ and $\mathrm{P}-\mathrm{O}-\mathrm{H}$ bands at 990 and $1059 \mathrm{~cm}^{-1}$. Upon addition of the Ni-salt (111 min) the intensities of the characteristic bands decrease abruptly due to the dilution of the linker solution. Subsequently the intensities of these bands decrease further (within $33 \mathrm{~min}$ ), while new bands at $1011(\mathrm{P}=\mathrm{O}), 1090(\mathrm{C}-\mathrm{O}-\mathrm{H})$ and $1101(\mathrm{P}(=\mathrm{O})-\mathrm{O}-\mathrm{H}) \mathrm{cm}^{-1}$ that are due to the formation of the final product are observed.

In order to elucidate the origin of the higher crystallisation rate upon ultrasonication of the reaction mixture as observed in the in situ EDXRD investigations, reactions starting from a clear solution and from a dispersion of the ligand were carried out at the same temperature $\left(50^{\circ} \mathrm{C}\right)$ as the EDXRD experiments. The in situ IR-spectra of the measurement starting from clear solutions are shown in Fig. 10C and D. Upon addition of the Ni-salt solution $(\sim 110 \mathrm{~min})$ the bands which are due to the formation of $\left[\mathrm{Ni}\left(\mathrm{H}_{2} \mathrm{O}\right)_{4}\left(\mathrm{H}_{2} \mathbf{P M B C}\right)_{2}\right](1011,1090$ and $1101 \mathrm{~cm}^{-1}$ ) evolve to maximal intensity within approximately 10 minutes. A quantitative comparison of the two in situ investigations at $50^{\circ} \mathrm{C}$ is shown in Fig. 12. To evaluate the crystallisation process quantitatively, the characteristic

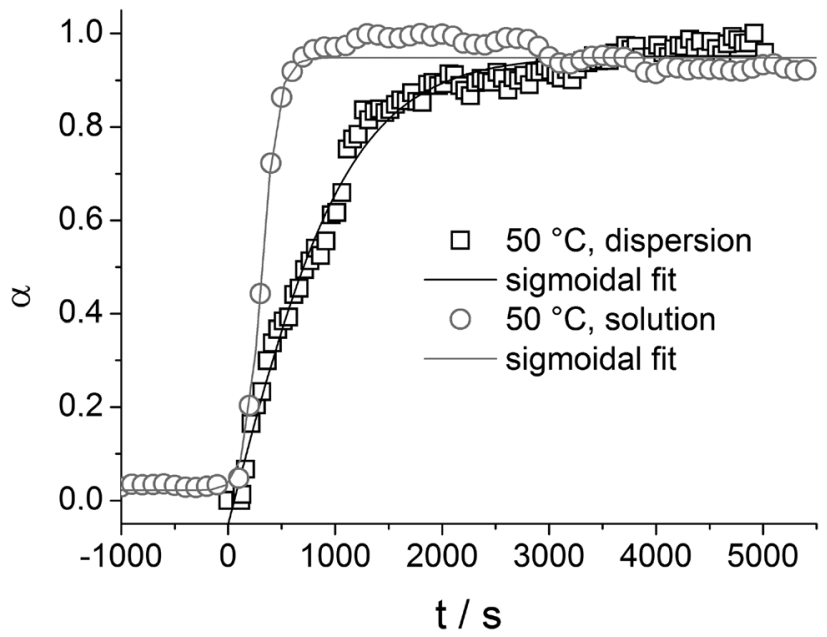

Fig. 12 Reaction progress $(\alpha)$ measured via in situ IR spectroscopy starting from a dispersion of the linker (squares) and clear solutions (circles).

$\mathrm{P}=\mathrm{O}$ band of $\left[\mathrm{Ni}\left(\mathrm{H}_{2} \mathrm{O}\right)_{4}\left(\mathrm{H}_{2} \mathbf{P M B C}\right)_{2}\right]$ at $1011 \mathrm{~cm}^{-1}$ was integrated. In order to compensate for variations of the absolute intensities the integrated intensity of the water band at $1636 \mathrm{~cm}^{-1}$ was used as a standard. The intensities of the $\mathrm{P}=\mathrm{O}$ band were normalised in order to calculate the reaction progress $\alpha$ (Fig. 12).

The product formation starting from a clear solution is far more rapid than in the case of a ligand dispersion as the starting material. In the first case the product formation is complete by approximately $10 \mathrm{~min}$, while in the latter case it takes approximately $80 \mathrm{~min}$. Thus, the acceleration of the synthesis through ultrasonication that was observed in the in situ EDXRD investigation can be attributed to the accelerated dissolution of the ligand.

\section{Conclusion}

Using high-throughput ultrasonic synthesis two new compounds, $\left[\mathrm{Ca}\left(\mathrm{H}_{2} \mathrm{O}\right)_{2}\left(\mathrm{H}_{2} \mathbf{P M B C}\right)_{2}\right]$ and $\left[\mathrm{Ni}\left(\mathrm{H}_{2} \mathrm{O}\right)_{4}\left(\mathrm{H}_{2} \mathbf{P M B C}\right)_{2}\right]$, were discovered. Their crystal structures were determined from single-crystals which were obtained by conventional solvothermal synthesis. In situ EDXRD and IR spectroscopies have allowed us to determine the role of ultrasonication in the acceleration of the formation of $\left[\mathrm{Ni}\left(\mathrm{H}_{2} \mathrm{O}\right)_{4}\left(\mathrm{H}_{2} \mathbf{P M B C}\right)_{2}\right]$. The rate determining step was found to be the dissolution of the ligand $\mathrm{H}_{3} \mathbf{P M B C}$.

\section{Acknowledgements}

We are thankful for single-crystal X-ray diffraction measurements by Inke Jeß. The in situ IR spectroscopy experiments were carried out with the kind support of Nicole Pienack and Wolfgang Bensch. Financial support by the DFG (SPP 1415) is gratefully acknowledged. 


\section{References}

1 R. B. N. Baig and R. S. Varma, Chem. Soc. Rev., 2012, 41, 1559-1584.

2 K. S. Suslick, Science, 1990, 247, 1439-1445.

3 A. Tahmasian and A. Morsali, Inorg. Chim. Acta, 2012, 387, 327-331.

4 Z.-Q. Li, L.-G. Qiu, W. Wang, T. Xu, Y. Wu and X. Jiang, Inorg. Chem. Commun., 2008, 11, 1375-1377.

5 W.-J. Son, J. Kim, J. Kim and W.-S. Ahn, Chem. Commun., 2008, 6336-6338.

6 S. Bernt, M. Feyand, A. Modrow, J. Wack, J. Senker and N. Stock, Eur. J. Inorg. Chem., 2011, 2011, 53785383.

7 G. Cravotto, E. C. Gaudino and P. Cintas, Chem. Soc. Rev., 2013, 42, 7521-7534.

8 N. Stock and S. Biswas, Chem. Rev., 2011, 112, 933-969.

9 J. H. Bang and K. S. Suslick, Adv. Mater., 2010, 22, 10391059.

10 K. S. Suslick and D. J. Flannigan, Annu. Rev. Phys. Chem., 2008, 59, 659-683.

11 P. Zhang, C. Fan, H. Lu, A. T. Kan and M. B. Tomson, Ind. Eng. Chem. Res., 2011, 50, 1819-1830.

12 A. Sonnauer, M. Feyand and N. Stock, Cryst. Growth Des., 2008, 9, 586-592.

13 Y.-N. Cao, X.-C. Chai, H.-H. Zhang and Q. Zheng, J. Solid State Chem., 2011, 30, 775; G. Chaplais, J. Le Bideau, D. Leclercq and A. Vioux, Chem. Mater., 2003, 15, 19501956; H.-H. Z. Jin Hu, Y.-N. Cao, C.-G. Zhang, S. Zhang, Y.-P. Chen and R.-Q. Sun, Chin. J. Struct. Chem., 2009, 28, 939-946; R. Lei, X. Chai, H. Mei, H. Zhang, Y. Chen and Y. Sun, J. Solid State Chem., 2010, 183, 1510-1520; R. Lei, H.-H. Zhang, J. Hu, X.-C. Chai, S. Zhang, C.-X. Li, Y.-P. Chen and Y.-Q. Sun, Chin. J. Struct. Chem., 2010, 29, 655-659.

14 N. Stock and T. Bein, Angew. Chem., Int. Ed., 2004, 43, 749752.

15 N. Stock and T. Bein, J. Mater. Chem., 2005, 15, 1384-1391.

16 D. Witt and J. Rachon, Phosphorus, Sulfur Silicon Relat. Elem., 1996, 108, 169-187.

17 N. Pienack and W. Bensch, Angew. Chem., Int. Ed., 2011, 50, 2014-2034.

18 Y. Aoki, H. Tominaga and M. Nagai, Catal. Today, 2013, 215, 169-175.

19 D. Duffy, M. Barrett and B. Glennon, Cryst. Growth Des., 2013, 13, 3321-3332.
20 M. Behrens, R. Kiebach, J. Ophey, O. Riemenschneider and W. Bensch, Chem.-Eur. J., 2006, 12, 6348-6355; D. O'Hare, J. S. O. Evans, A. Fogg and S. O'Brien, Polyhedron, 2000, 19, 297-305; F. Millange, C. Serre, N. Guillou, G. Férey and R. I. Walton, Angew. Chem., Int. Ed., 2008, 120, 4168-4173.

21 N. Pienack, C. Näther and W. Bensch, Eur. J. Inorg. Chem., 2009, 2009, 937-946.

22 R. Kiebach, N. Pienack, W. Bensch, J.-D. Grunwaldt, A. Michailovski, A. Baiker, T. Fox, Y. Zhou and G. R. Patzke, Chem. Mater., 2008, 20, 3022-3033; E. Antonova, B. Seidlhofer, J. Wang, M. Hinz and W. Bensch, Chem.-Eur. J., 2012, 18, 15316-15322; Y. Zhou, E. Antonova, Y. Lin, J.-D. Grunwaldt, W. Bensch and G. R. Patzke, Eur. J. Inorg. Chem., 2012, 2012, 783-789; Y. Zhou, E. Antonova, W. Bensch and G. R. Patzke, Nanoscale, 2010, 2, 2412-2417; Y. Zhou, N. Pienack, W. Bensch and G. R. Patzke, Small, 2009, 5, 1978-1983; A. Michailovski, R. Kiebach, W. Bensch, J.-D. Grunwaldt, A. Baiker, S. Komarneni and G. R. Patzke, Chem. Mater., 2006, 19, 185-197; A. Michailovski, J.-D. Grunwaldt, A. Baiker, R. Kiebach, W. Bensch and G. R. Patzke, Angew. Chem., Int. Ed., 2005, 44, 5643-5647.

23 R. Kiebach, N. Pienack, M.-E. Ordolff, F. Studt and W. Bensch, Chem. Mater., 2006, 18, 1196-1205; R. Kiebach, M. Schaefer, F. Porsch and W. Bensch, Z. Anorg. Allg. Chem., 2005, 631, 369-374.

24 Y. Zhou, Q. Zhang, Y. Lin, E. Antonova, W. Bensch and G. R. Patzke, Sci. Chin. Chem., 2013, 56, 435-442.

25 N. Stock, Microporous Mesoporous Mater., 2010, 129, 287295.

26 L. Engelke, M. Schaefer, M. Schur and W. Bensch, Chem. Mater., 2001, 13, 1383-1390.

27 G. M. Sheldrick, SHELXL-97, A Program Package for the Solution and Refinement of Crystal Structures, Universität Göttingen, 1997.

28 G. Socrates, Infrared and Raman Characteristic Group Frequencies - Tables and Charts, Wiley-VCH, Weinheim, 2004.

29 F. Millange, R. El Osta, M. E. Medina and R. I. Walton, CrystEngComm, 2011, 13, 103-108; F. Millange, M. I. Medina, N. Guillou, G. Férey, K. M. Golden and R. I. Walton, Angew. Chem., 2010, 122, 775-778; E. Stavitski, M. Goesten, J. JuanAlcañiz, A. Martinez-Joaristi, P. Serra-Crespo, A. V. Petukhov, J. Gascon and F. Kapteijn, Angew. Chem., 2011, 123, 97989802.

30 M. Feyand, A. Hübner, A. Rothkirch, D. S. Wragg and N. Stock, Inorg. Chem., 2012, 51, 12540-12547. 